\title{
IUELTAL
}

\section{An Investigation into Teachers Practices of Teaching Early Reading and Practical problems in Its Implementation}

\author{
Minwuyelet Andualem Desta \\ Debre Tabor University, Ethiopia \\ Email:minwuyezoo8@gmail.com
}

\begin{abstract}
:
The purpose of this study was to investigate practices of teaching early reading, and challenges teachers face in its implementation at the Ethiopian primary schools. The study was carried out in 224 grade two government primary schools found in the Amhara National regional State, west Gojjam zone, Ethiopia, in 2019/2020 academic year. To attain this objective, a descriptive research design was employed. The participants of the study were 112 English language teachers enrolled in the primary schools at Dembecha woreda, Jiga woreda, Jabitehinan woreda, and Bure woreda in west Gojjam zone. Interview, questionnaire, and observation were used to gather data. The findings revealed that teachers failed to practice the teaching of early reading in line with the purposes and principles of teaching early reading. Teachers used traditional way of teaching approach in teaching reading. The study also showed that teachers are deficiently trained regarding phonological awareness, alphabetic principle, reading comprehension, oral fluency, vocabulary, and phonemic awareness. Besides, lack of teachers training, lack of materials, and unrelated educational qualification were major impediments of teachers while implementing teaching early reading. Finally, it was recommended that teachers be given trainings about methods of English language teaching in general, and teaching early reading in particular.
\end{abstract}

Keywords: challenges, early reading, practice of teaching early reading

\section{Introduction}

Reading requires one to identify and understand strings of words in a fluid manner. It is a detailed process that includes comprehension, word recognition, engagement, and oral fluency. Reading literacy is directly related to the reasons why people read. Broadly, these 
reasons include reading for personal pleasure, reading to participate in society, and reading to learn (Sanders, 2017). Without the ability to read, a child cannot fully access his or her democratic rights. To be a good reader, you'll be able to progress through your assignments faster and be able to retain more information than if as an unskilled reader (Nun, 2013, and Phillips, 2009). What makes up "good" reading skills? Good vocabularies, which include pronunciation and spelling, the speed with which you read, and how much you understand after reading something. Reading skill is important for children's intellectual development. It helps them learn new words, their pronunciation, spelling, and how to correctly use them (senior 2005). Harmon (2009) points out that children who are not reading fruitfully in the class room will progressively disengage from instruction, disrupt their peers, fall further behind in reading and establishing a pattern of reading failure.

Hodge, (2011), pointed out reading has been used for many years in narrow sense which indicates to a set of print based decoding and thinking skills necessary to understand the text. It is a very complex developmental challenge that we know to be intertwined with many other developmental accomplishments; attention, memory, language, motivation and the like (pp. 54). Now a days, our understanding in line with reading has been broadened to involve the visual and thinking skills necessary to get data from digital video, handheld data assistants, computers, or other technological learning environment (Brawl, 2010). The idea that visual and thinking skills needed for getting information today are formed by increasingly distinct social or cultural settings found in schools, homes, communities, or ethnic groups (Morrow, 2012). Consequently, the word reading is currently interpreted far more broadly and encompasses learning of a complex set of skills and ability that permits individuals to understand visual and print-based information. The main aim of reading instruction, hence, is motivating readers to learn, grow, and participate in a vibrant and quick changing information-based world (John, 2015).

When children start learning to read, they want to get a set of knowledge, and strategies that will assist them reach the ultimate goal associated with learning to read: comprehending what they read whether in traditional print forms or more technologybased formats. With regard to the purpose of reading skills that is, understanding the author's message - children should procure a set of early reading skills or instruments that involve like; hearing individual sounds in spoken words, understanding, identifying letters and increasing oral language vocabularies etc. (Gateman, 2014). Anderson (2009) has pointed out that the need and ability to learn to read often grow out of children's initial inquisitiveness about how to write letters and words. Therefore, writing quite often delineates not only the starting point in many children's way fare to learn to read but also the finish line as the whole.

At the beginning, young children become aware of letters and words in the world around them. Scott (2008) notified that teachers' wakefulness about effective reading instruction makes the single greatest difference in whether or not every child will have an equal and effective opportunity to learn to read efficiently in first cycle primary schools. Each features of reading instruction is described in terms of what highly effective reading teachers should know and be able to do to give effective in assisting body members generalized that teachers' awareness and ability is important for students to become powerful readers. Research findings implied that teachers' overall instructional ability and awareness are strongly related to students' achievement (Greenwald, 2011). A number of studies now 
reveal a strong association between what teachers know about the teaching of reading and their students' accomplishment in reading (Burns, 2007). Addressing the students' needs in learning to read in today's increasingly prominent classroom environment can be intricate and challenging learning obstacles. Children's ability to thrive from reading instruction can be affected by a number of obstacles, including emotional, behavioral, and intellectual disabilities (Brown, 2016).

The only way to provide solid instruction that addresses the needs of learners having special needs in today's classrooms, on the other hand, is to follow what is called "differentiating instruction" (Bolton \& Crux, 2012). Successful teachers give instructions that is responsive to specific desires of every child based on continuing assessment results. Reading instruction must include both teaching pillars of reading skills and practices along with reading and other English language skills. The pillars are phonological wakefulness, alphabetic principle, reading comprehension, reading for knowing new words, phonemic awareness, the ability to recognize meanings of words and their uses in varying contexts; oral reading fluency, reading with speed and accuracy, as well as with the correct stress, intonation, and emphasis; and actively working to make sense of a text by constantly integrating what is being learned in the text with what is known from experiences. These pillars are at the heart of teaching early reading. Teachers must have clear understanding regarding these pillars to assist learners' learning effectively.

In Ethiopia, studies have shown that the ability of learners to read simple letters, words, phrases, and sentences are below the expected one. Hence, the quality of reading results here in Ethiopia is declining slightly (Tina, 2011). The low achievement in English language skills particularly, in reading skill is very interesting, the gap, is in children's ability to read, decode, and comprehend written text (Giza, 2013, Harmon, 2009 \& Tina, 2013). In Ethiopia, the assessment report made by Ministry of Education (2019), that early grade reading assessment clearly implies that insignificant reading instruction is encountering in a number schools and students are not learning to read. The achievement of students in reading skill is very low.

Furthermore, the main factor that motivated the researcher to conduct this study on this topic is that the researcher's experience. As one of EFL teachers in the primary schools, he shared experiences from his colleagues in the schools. When students were asked to read a simple paragraph/passage at lower grades in general, and grade two level in particular, in reality, it is contradicted with what is said to be the appropriate of administering. That is to mean, when it comes to students reading skills, it is very low, and the result achieved remains unsatisfactory. More than fifty percent of children in Ethiopia in general, and in the Amhara national regional state (ANRS), west Gojjam zone in particular, are unable to answer simple reading comprehension skill questions.

This observed problem inspired the researcher to look into study on this topic. Moreover, when it comes to region's children's achievement regarding reading comprehension skill, an assessment report by ANRS education bureau (2020) has indicated that $51.2 \%$ of children were are not able to read one word in grade two, and even at the end of grade three. Thus, assessing practices of teaching early reading on this grade level, therefore, needs to be treated with great care, attention, and respect to enhance learners' future academic progress. This is therefore, crucial to investigate teachers' practices of teaching early 
reading and challenges they face while implementing it in the classrooms among grade two English language teachers.

\section{Literature Review}

It is expected that reading skills are fundamental to a child's access to print for academic growth, interaction with society and to provide an alternative mode of communication for each of us in today's ever advancing world of technology. From pre-school through third grade, children are typically taught fundamental skills to learn to read. By third grade and beyond, children use reading skills to acquire new academic knowledge (Kim, 2010). According to the National Assessment of Adult Literacy report (2017) fifty four percent of adults with below basic literacy skills did not graduate from high schools. Twenty-one percent of adults with below basic literacy skills had multiple disabilities. It is estimated that more than $16 \%$ of children in Ethiopia have one or more developmental disabilities that impacts their reading development, and $1.5 \%$ of the population have disability that impacts their ability to use speech as primary means of communication, making augmentative and alternative communication systems etc. (Bus, 2012). The ability to read has an implications for communication improvement to individuals who use alternative communication systems. Access to print for generative language provides flexible system in which to create novel messages and interact with families, friends, and peers (Marsh, 2014).

In the same vein, Burns (2014), reading intervention for children who use supplement and alternative communication systems have focused on language instruction to build comprehension of vocabulary, story structure, and other language skills. Several studies to date demonstrate engaging approaches with books to encourage language learning in combination with children's augmentative and alternative communication systems, even if limited work to date has evaluated approaches in teaching skills of phonological awareness and word decoding (Rao, 2013). The simple view of reading characterizes reading ability as the product of language comprehension and word decoding. Very few studies have examined the impact of teaching both comprehension and decoding skills within an intervention to children with limited speech. The basic reading skills necessary to become "literate" do not develop naturally; we have to learn to adapt the part of our brain that recognizes images to be able to recognize written letters and words (Wolf, 2007).

As has been confirmed by scholars working to understand reading acquisition in multiple languages (Thompson and Vaughn, 2007), in almost any alphabetic language in which print can be decoded broken apart mentally into sounds being able to read well requires grasp of seven basic skills (National Early Reading Literacy Panel, 2008). These important pillars of reading are phonological awareness, alphabetic principle, reading comprehension, phonemic awareness, vocabulary, and reading oral fluency at all. Reading creates the door to children's early academic success, and leads to higher grades in every subject. When children learn to read at early age, they have greater general knowledge, expand their vocabulary and become more fluent readers (pp.71). Early readers can recall a number of words by sight, which enables them to learn more from and about their environment. Their proficiency in reading enables them to comprehend more of what they are reading. They also become competent researchers who are able to study effectively and extract relevant and necessary information from books, magazines, or other sources of information (Luckner, 2013). 
Early reading promotes greater maturity, and lays the basis for moral literacy. In addition, it motivates the child's creativity and imagination in learning. What's more, when children start learning to read at the age of two or three, there is no psychological pressure (Balchard, 2015). Early readers have the opportunity to relate their peers on more competent as they are already being recognized for their accomplishments. Children who can read independently and early have more opportunities to encounter the written word. The sooner children learn how to read, the more books, knowledge, and ideas they will be exposed to (Wagner, 2011).

\subsection{Factors Influencing Early Reading}

There are a number of factors that can be attributed to influence teachers' pedagogical role in the practices of teaching reading. Lack of facilities, lack of supplementary materials, a mismatch between teachers' background and the course what they were teaching in the schools, lack of training that entails lack of awareness are some of the factors among others, to be discussed afterwards for the purpose of this study. Teachers' awareness of practicing teaching early reading has their origins in their prior experiences, and these conceptualization affect their current practices about how to teach in the classroom.

In teaching reading skill in early grades in particular, the teachers' prior learning experiences as learners and in teacher education are major influences on the teachers' conceptions which ultimately affect their current teaching approach (Mokiwa1, 2013). For example, research findings on various instructional approaches such as the use of inquiry based practices (Lotter, 2007) \& the constructivist model of teaching (Shumba, 2011) have revealed that teachers' understanding in teaching has played a major role in shaping their instructional practices in early grade contexts. This indicates that teachers awareness of teaching constitute an indispensable part of their instructional and student learning processes in teaching early reading.

Also, decoding is common factor for beginner readers to influence when they meet new or unfamiliar terms because it is a vital step in the reading process (Burns, 2014). When beginner readers encounter vocabulary, they do not know or recognize owing to inaccurate decoding, they are likely to pass ahead. The more blanks in a line of text, the harder it is to make meaning and the more cognitively challenging and frustrating the reading tasks (Scott, 2008). That is why poor comprehension can result when a students' struggle with decoding has a limited vocabulary or attempts to read a text that is at too high level. Furthermore, large class size, and lack of supplementary materials are also common challenges while implementing teaching reading skill in early grades.

\section{Research Methodology}

In this study, descriptive research design which applies quantitative and qualitative methods of data collection was employed. This is because, it is applicable to obtain valuable information about teachers' practices of teaching early reading, and challenges they face in its implementations. This research design is preferred over others because it provides answers for the questions of who, what, when, where, and how in relation to this particular research problem (Kothari, 2004). Target participants were grade two English language teachers at selected primary schools of west Gojjam zone, Ethiopia. The instruments used to collect data for the study were interview, questionnaire, and observation. These 
instruments were selected because of their suitability for gathering important data for the study. Thus, semi-structured interview was conducted for sample grade two English language teachers who were teaching at the selected primary schools. semi structured interview was deliberately selected to obtain valuable information about teachers practices of teaching early reading, and challenges they face while practicing teaching early reading. Since it is more flexible to collect the data for this study. Interview was conducted to ten teachers to crosscheck the data gathered through the questionnaire.

To get additional information to the data obtained through interview, questionnaire was used as data collection instrument and designed to collect relevant data from the sample grade two English teachers. The questionnaire items were prepared to assess teachers' practices of teaching early reading at schools. The students are seven to nine years old, and one cannot expect them to fill a questionnaire so that the questionnaire was only filled by the teachers. To gather data from teachers, closed ended questionnaire items were set both in English and Amharic. The questionnaire consisted of three parts. The first part was about teachers' background. The second part dealt with trainings teachers receive or not regarding pillars of early reading in their teaching and learning contexts. The final part was about how often teachers practice reading pillars in early grades. Here, five point likerrating scale ranging from 'always' to 'Never' items were used.

Also, the researcher selected fifteen of the teachers randomly and observed each of them three times using structured observation checklist. This was intended to investigate teachers reading lessons practice regarding to pillars of early reading in the class room. Accordingly, the classrooms teachers were observed to triangulate whether what the teachers' responses to the questionnaire and interview questions match what they actually did in the class room. The responses of close ended questionnaire were analyzed, and described quantitatively through descriptive statistics using SPSS version 17. Cronbach's alpha was utilized to measure the level of reliability of the questionnaire. However, the data collected through using interview were analyzed qualitatively through using narrative form and in an interpretive manner.

\section{Findings}

As the data can be indicated in the table below, the background was meant to find out information from teachers about their profession and teachers training institutions they are attended.

Table 1. Teachers backgrounds who responded to the Questionnaire

\begin{tabular}{|c|c|c|c|c|c|c|c|c|c|c|c|c|c|c|c|c|c|c|c|c|c|c|c|c|c|c|c|}
\hline \multirow{2}{*}{\multicolumn{2}{|c|}{$\begin{array}{l}\mathrm{EQ} \\
10+2\end{array}$}} & \multicolumn{18}{|c|}{ Teachers Course Subjects } & \multicolumn{8}{|c|}{ Training Institutions } \\
\hline & & 10 & & Ens & & AN & & $\mathrm{LC}$ & & GY & & SS & & MT & & CS & & SC & & FM & & DMS & & BUF & & $\mathrm{BDF}$ & \\
\hline $\begin{array}{l}\mathrm{N} \\
\mathrm{O}\end{array}$ & $\%$ & $\begin{array}{l}\mathrm{N} \\
\mathrm{O}\end{array}$ & $\%$ & $\begin{array}{l}\mathrm{N} \\
\mathrm{O}\end{array}$ & $\%$ & $\mathrm{~N}$ & $\%$ & $\mathrm{~N}$ & $\%$ & $\begin{array}{l}\mathrm{N} \\
\mathrm{O}\end{array}$ & $\%$ & $\begin{array}{l}\mathrm{N} \\
\mathrm{O}\end{array}$ & $\%$ & $\begin{array}{l}\mathrm{N} \\
\mathrm{O}\end{array}$ & $\%$ & $\begin{array}{l}\mathrm{N} \\
\mathrm{O}\end{array}$ & $\%$ & $\begin{array}{l}\mathrm{N} \\
\mathrm{O}\end{array}$ & $\%$ & $\begin{array}{l}\mathrm{N} \\
\mathrm{O}\end{array}$ & $\%$ & \begin{tabular}{l|l}
$\mathrm{N}$ & 0 \\
$\mathrm{O}$ & \\
\end{tabular} & $\%$ & \begin{tabular}{l|l}
$N$ & \\
$O$
\end{tabular} & $\%$ & & $\%$ \\
\hline 9 & $\begin{array}{l}J \\
2 \\
7 \\
7\end{array}$ & 3 & 3 & 6 & $\begin{array}{l}1 \\
1 \\
1\end{array}$ & 7 & 1 & $\perp$ & 7 & 4 & 6 & 3 & . & 5 & $\begin{array}{l}4 \\
5 \\
5\end{array}$ & 9 & 8 & $\begin{array}{l}1 \\
3\end{array}$ & $\begin{array}{l}1 \\
1 \\
6 \\
6\end{array}$ & $\begin{array}{l}5 \\
4\end{array}$ & $\begin{array}{l}4 \\
8\end{array}$ & 5 & 2 & $\begin{array}{l}2 \\
1\end{array}$ & $\begin{array}{l}8 \\
8\end{array}$ & & 0 \\
\hline
\end{tabular}

\{Key words: EQ = Educational Qualifications, Eng. = English, AM = Amharic, LC = Language Cluster, GY = Geography, SS = Sport Science, MT= Mathematics, CS = Civics, SC = Science, $\mathrm{FM}=$ Finote Selam, DM = Debre Markos, BUR = Bure, BDR = Bahir Dar $\}$ 
In this regard, and as it can be seen from the table above, 59(52.7\%) of the teachers are Diploma holder from among the total population. Similarly, only $31(27.7 \%)$ was covered by English language graduate teachers. Again, $81(72.3 \%)$ of the whole population was covered by the other department graduate teachers. Those are, diploma in Amharic, diploma in language clusters, diploma in Geography, diploma in Sport science, diploma in Mathematics, diploma in civics, diploma in Science and the like. From this data, one can conclude that $41.1 \%$ of teachers didn't have related area of study to teach English language in first cycle primary schools in general, and grade two in particular. Besides, the data obtained through teachers' interview, the researcher deduced that grade two English language teachers were selected from distinct area of study.

Table 2. Teachers responses regarding to trainings they receive in relation to Pillars of Reading

\begin{tabular}{llllll}
\hline \multirow{2}{*}{\multicolumn{1}{c}{ Training Types }} & \multicolumn{5}{c}{ Responses } \\
\cline { 2 - 5 } & Yes & \multicolumn{3}{c}{ Total } \\
\cline { 2 - 5 } & $\mathrm{N}$ & $\%$ & $\mathrm{~N}$ & $\%$ & \\
\hline Phonological awareness & 17 & 15.2 & 95 & 84.8 & 112 \\
\hline Alphabetic principle & 21 & 18.6 & 91 & 81.3 & 112 \\
\hline Reading comprehension & 28 & 25 & 84 & 75 & 112 \\
\hline Oral fluency skills & 15 & 13.4 & 97 & 86.6 & 112 \\
\hline Vocabulary instruction & 32 & 28.57 & 80 & 71.4 & 112 \\
\hline Phonemic Awareness & 11 & 9.8 & 101 & 90.17 & 112 \\
\hline
\end{tabular}

$\{$ Key: $\mathrm{N}=$ Number, $\%=$ Percent, $\mathrm{T}=$ Total $\}$

With regard to the data stated in the above table, $15.2 \%$ of the respondents replied that they took trainings regarding phonological awareness in the teachers training centers. Concerning to the alphabetic principle of reading pillar, only $21(18.6 \%)$ replied that they took trainings in relation to alphabetic principles in the teachers training centers. Besides, $28(25 \%)$ reported that they received short term trainings in relation to reading comprehension skills while their teaching. In the same vein, only 15(13.4\%) of teachers got trainings about reading for oral fluency skills at the teachers training institutions. In vocabulary and phonemic instructions, on the other hand, only 32 (28.57) \& 11 (9.8\%) respondents informed that they took procedural trainings regarding these pillars in their teaching and learning walks of life respectively. Similarly, the data obtained through interview item, participants reported that trainings they got were not as such adequate to assist them teach reading skill, and other English language skills as well.

Table 3: Teachers' responses regarding to practice of teaching pillars of early reading

\begin{tabular}{|c|c|c|c|c|c|c|c|c|c|c|c|c|}
\hline \multirow[t]{3}{*}{ No } & \multirow{3}{*}{ Items } & \multicolumn{11}{|c|}{ Responses } \\
\hline & & \multicolumn{2}{|l|}{ A } & \multicolumn{2}{|l|}{$U$} & \multicolumn{2}{|l|}{$\mathrm{S}$} & \multicolumn{2}{|l|}{$\mathrm{R}$} & \multicolumn{2}{|l|}{$\mathrm{N}$} & \multirow{2}{*}{$\frac{T}{112}$} \\
\hline & & $\mathrm{N}$ & $\%$ & $\mathrm{~N}$ & $\%$ & $\mathrm{~N}$ & $\%$ & $\mathrm{~N}$ & $\%$ & $\mathrm{~N}$ & $\%$ & \\
\hline 1 & $\begin{array}{l}\text { How often do you teach } \\
\text { phonological instructions }\end{array}$ & 23 & 20.5 & 37 & 33 & 15 & 13.4 & 19 & 16.9 & 18 & 16.1 & 112 \\
\hline 2 & $\begin{array}{l}\text { How often do you teach } \\
\text { about alphabetic principles }\end{array}$ & 21 & 18.8 & 34 & 30.4 & 27 & 24.1 & 15 & 13.4 & 15 & 13.4 & 112 \\
\hline
\end{tabular}




\begin{tabular}{|c|c|c|c|c|c|c|c|c|c|c|c|c|}
\hline 3 & $\begin{array}{l}\text { How often do you teach } \\
\text { reading comprehension } \\
\text { strateaies }\end{array}$ & 33 & 29.5 & 22 & 19.6 & 29 & 25.9 & 16 & 14.3 & 12 & 10.7 & 112 \\
\hline
\end{tabular}

\{Key: $\mathrm{A}=$ Always, $\mathrm{U}=$ Usually, $\mathrm{S}=$ Sometimes, $\mathrm{R}=$ Rarely, $\mathrm{N}=$ Never, $\mathrm{T}=$ Total $\}$

As the data can be described in the above table, from among respondents, $20.5 \%$ of teachers replied that they do this always and 37(33\%) of them do so usually. Furthermore, $13.4 \%$ of the respondents divulge that they teach phonological instructions only sometimes at schools. The $16.1 \%$ of teachers, on the other hand, replied that they do not teach it at all. The information obtained from class room observations implied that teachers were not seen practicing this reading pillar in all teachers' class room observation times. From here, it is possible to say that grade two English teachers have no conceptions regarding teaching phonological skill in real classrooms. Concerning to the data stated in item 2, teachers were asked whether they implement the alphabetic principles in teaching early reading or not.

The stated information implied that $21(18.8 \%)$ and $34(30.4 \%)$ respectively revealed that they always and usually practice the alphabetic principles in the teaching early reading. Whereas, $15(13.4 \%)$ divulged that they do not practice it at all. In line with this, the data gained from the class rooms observations shows that the teachers were not teaching this pillar in the classrooms at all. It seems that teachers may lack awareness regarding principles of alphabet. Also, respondents' responses in item 3 showed that 33(29.5\%) teachers teach the reading comprehension skill always, and 22(19.6\%) of them do so usually at schools respectively. On the contrary, in the $77 \%$ of the teachers' lessons presentation, they never do so at all. Even if more than half of the teachers demanded that they always, and usually teach this reading pillar, the data from the teachers' classroom lessons observation seem to disconfirm the teachers demand at all

Table 4: Teachers' responses regarding to practice of teaching pillars of early reading

\begin{tabular}{|c|c|c|c|c|c|c|c|c|c|c|c|c|}
\hline \multirow[t]{3}{*}{ No } & \multirow[t]{3}{*}{ Items } & \multicolumn{11}{|c|}{ Responses } \\
\hline & & \multicolumn{2}{|c|}{$A$} & \multicolumn{2}{|c|}{ U } & \multicolumn{2}{|c|}{$S$} & \multicolumn{2}{|r|}{$\mathrm{R}$} & \multicolumn{2}{|r|}{$\mathrm{N}$} & \multirow{2}{*}{$\begin{array}{c}\mathrm{T} \\
112\end{array}$} \\
\hline & & $\mathrm{N}$ & $\%$ & $\mathrm{~N}$ & $\%$ & $\mathrm{~N}$ & $\%$ & $\mathrm{~N}$ & $\%$ & $\mathrm{~N}$ & $\%$ & \\
\hline 4 & $\begin{array}{l}\text { How often do you } \\
\text { teach about oral } \\
\text { fluency }\end{array}$ & 24 & 21.4 & 28 & 25 & 15 & 13.4 & 13 & 11.6 & 22 & 19.6 & 112 \\
\hline 5 & $\begin{array}{l}\text { How often do you } \\
\text { teach reading for } \\
\text { knowing new words }\end{array}$ & 19 & 16.9 & 27 & 24.1 & 17 & 15.2 & 30 & 26.8 & 19 & 16.9 & 112 \\
\hline 6 & $\begin{array}{l}\text { How often do you } \\
\text { teach about phonemic } \\
\text { instructions }\end{array}$ & 5 & $4 \cdot 5$ & 23 & 20.5 & 15 & 13.4 & 31 & 27.7 & 38 & 33.9 & 112 \\
\hline
\end{tabular}

\{Key: $\mathrm{A}=$ Always, $\mathrm{U}=$ Usually, $\mathrm{S}=$ Sometimes, $\mathrm{R}=$ Rarely, $\mathrm{N}=$ Never, $\mathrm{T}=$ Total $\}$

As the data can be put in item 4, 24(21.4\%) teachers told that they always teach oral fluency skill in their classrooms. The $11.6 \%$ and $19.6 \%$ teachers, on the other hand, exploit this pillar rarely and never accordingly. As the information obtained through teachers' class room observation, the teachers were not experiencing in practicing this reading pillar at schools. This seems that teachers are not practicing teaching oral fluency skills at early grades in general, and grade two in particular. Also, the data which is indicated in item 5, 19(16.9\%) 
teachers practice teaching vocabulary instruction at early grades always, and $27(24.1 \%)$ of them do so usually at all. Furthermore, $4.5 \% \& 9.8 \%$ of teachers were always practicing about phonemic instructions. In this regard, the information obtained from classroom observations implied that less than half of school teachers teach phonemic instructions for reading always and usually at schools.

Interview was conducted for teachers so as to get more information regarding challenges they face while practicing teaching reading skills in early grades. From the interview results, the researcher find out that challenges that influence teachers' practices of teaching early reading. The information gained from teachers showed that there was a mismatch between the teachers' educational background and the course what they were teaching in the schools. In line with this, teachers $\left(T_{2}, \& T_{4}\right)$ replied that they had lack of awareness regarding pillars/components of reading comprehension due to their education background. Respondents reported that they do not know what they were teaching in the classroom. This is because, most of the teachers were assigned to teach early reading without their profession $\left(T_{1}, T_{6}, \& T_{9}\right)$. Besides, the results gained from the majority of interviewees/ respondents revealed that there have no training opportunities regarding the practice of teaching early reading at schools. Concerning this, teachers emphasized that to teach reading skill in early grades effectively, short term trainings should be provided for teachers $\left(\mathrm{T}_{7}\right.$, and $\left.\mathrm{T}_{10}\right)$.

Teachers also replied that there were lack of teaching supplementary materials at schools (for example; $T_{31} T_{51}$ and $T_{7} \& T_{8}$ ). This hinders teachers to practice it at schools. Also, large number of learners per class was too big so that there was not conducive environment to practice teaching reading in the early grades at the selected schools. Most of the teachers mentioned that large number of learners made it difficult for them to give individual attention to learners (e.g. $T_{2}, T_{31} T_{51}$ and $T_{9}$ ). Overall, participants mentioned that there are a number of factors that can be attributed to influence their pedagogical role in the practices of teaching reading skills in early grades. In recalling them, lack of supplementary materials, large class size, a mismatch between the teachers' background and the course what they were teaching in the schools, and lack of trainings that entail lack of awareness are the main impediments of teachers they face while practicing teaching early reading at schools.

\section{Discussion}

The main purpose of this study was to investigate teachers' practices of teaching early reading and practical problems in its implementations at the Ethiopian primary schools particularly, grade two students context. The results from the analysis of data from interview, \& questionnaire, and classroom observation are discussed in line with some empirical findings. Most of the schools teachers those who were teaching reading skills in early grades did not have appropriate educational backgrounds to teach early reading. As mentioned to the beginnings of the analysis section, the school teachers were from social sciences stream, foreign language, students L1 (mother tongue) stream, and natural sciences stream. According to the education principle, teachers those who did not get national certificates in the science of language teaching methodology cannot teach early reading and other language skills effectively. The subject course teachers those who teach early reading, on the other hand, are the ones who did not take courses in the aforesaid field of study. Based on this, one can possible to deduce that early grade teachers were disease 
trained and faced in lack of knowledge and skills of teaching English language. This finding is consistent with the findings of Faris (2011), who argued that teachers who were not professional in English language, and its teaching methodology, they could not gain improvements in their own teaching and learning walks of life.

This is because, teachers who are not professional in their field of study in general, and language teaching in particular, they do not know what to teach and how to teach reading skills in the teaching and learning way (Faris, 2011). Teachers those who are quite peculiar to the concept of pillars of teaching early reading are not successful in their teaching and learning way. This is resulted in producing poor readers those who are to be academically low achievers. The one who has good experiences of teaching early reading has significant influence on students' achievement in their future walks of life. The results of this study also corporate with the findings of Killer (2014), that teachers who have adequate knowledge of phonemic instruction, they could make their learners much more experienced about reading pillars in general, and phonemic instruction in particular.

Furthermore, the results obtained through the teachers class room observation in this regard generally revealed that most of the teachers did not teach reading and other English language skills effectively at schools. This is because, teachers were designated to teach early reading without their educational qualification. Learning to read, and other language skills has to be the heart of primary education curriculum in every academic world. Teachers those who teach reading and other language skills must be well trained for successful teaching and learning practices. This is consistent with the findings of Hanna (2012), that time given to reading instructions, and other language skills in the education curriculum should point out this reality. Moreover, this shows that children's reading and other language skills ability enhance students' togetherness (Shannon, 2010). In line with this, Paris (2009), pointed out that the literature asseverated that early grade teachers can motivate language and literacy development through play-based literacy instructions. Here, children must feel as though he or she is playing while teachers are teaching (Paris, 2009). However, this is inconsistent with the results obtained from teachers' class room observation that they did not achieve this activity in their own teaching early reading classrooms.

This result perceives to the researcher that all this is the findings of the teachers who did not get short term trainings in English language in general and teaching early reading in particular. As can be seen from the overall findings, this study clearly revealed that most of the teachers follow traditional instructional approach while teaching early reading at selected schools due to unrelated teachers' educational background and the course what they were teaching in the schools mentioned earlier, as challenges of teachers in practicing teaching early reading. On the contrary, this finding is inconsistent with the idea of Turner (2015), that teachers those who create good atmosphere, and follow excellent way teaching in daily class room discussions, they enable their learners active, critical readers and learners in their life. This is because, good readers have strategies that they practice so as to form meanings pre, while, and post reading skill (Wake, 2013).

\section{Conclusion}

Based the findings of the study, the following conclusion was drawn: The study mainly focused on teachers practices of teaching early reading at primary schools particularly, on 
grade two students at selected primary schools in west Gojjam zone, Ethiopia. Besides, challenges teachers face while practicing teaching early reading. Here, the findings revealed that most teachers' qualification, and field of study were far apart from what is required of them in teaching early reading. Teachers on the area of study were designated without having peculiar trainings to teach English course of grade two students in general and teaching early reading in particular. Teachers who were teaching at schools were employed without deliberating required qualification. This was arising from poor method of instructions, and hence, this is great impediment for effective practice of teaching early reading at all.

Teachers have lack of understanding regarding purposes and how to practice teaching early reading. Most teachers were not aware of practicing about pillars of reading in teaching early reading. Teachers are not as such skillful, and did not have conceptions what to teach and how to teach reading skills. Although, children's reading along with other language skill abilities specifically, reading skill ability promote students togetherness in their daily life experience, they didn't practice it as well. Besides, supplementary materials and large class size hinders teachers not to practice it in the classroom. Overall, the findings of the study revealed that majority of teachers were not giving emphasis for reading skills in their teaching and learning way. This idea is supported by Mani (2011), that though learning to read and other language skills are the heart for primary education curriculum, teachers give less concern on their own teaching.

\section{References}

Anderson, T. (2009). Research-based reading instruction: Myths about the National Reading Panel Report. The Reading Teacher, 51 (6), 541-562.

Best, J. \& Kahn, V. (2009). Research in Education, fifth Edition. New Delhi: Prenticer- Hall of India Private Ltd.

Bolton, G., \& Crux, S. (2012). Differentiated instructional strategies: One size doesn't fit all. Thousand Oaks, Calif: Corwin Press.

Brown, T. (2016). From Small-Group Reading Instruction: A Differentiated Teaching Model for Beginning and Struggling Readers. New York, DE: International Reading Association.

Burns, M. (2015). A brief report of the diagnostic accuracy of oral reading fluency, and reading inventory levels for reading failure risk among second- and third-grade students. Reading \& Writing Quarterly 31(1): 56-67.

Dornyei, Z. (2007). Research Methods in Applied Linguistics: Quantitative, Qualitative and Mixed Methodologies. Oxford: OUP.

Faris, T. (2011). Research on the reading-writing relationship: Interactions, transactions, and outcomes. In R. Barr, M.L. Kamil, P. Rosenthal, and P.D. Pearson (Eds.), Handbook of reading research (Vol. 3, pp. 345-390). New York: Longman.

Gateman, N. (2014).Teachers' attitude to and knowledge of metalinguistic in the process of learning to read. Asia-Pacific Journal of Teacher Education. 
Hana, C. (2012). Teachers Education handbook; Addis Ababa fin fine printing and publishing S.C.

Harmon, G. (2009). Using Storytelling to Develop Fluency and Literacy in Native American Languages". Northern Arizona University, College of Education.

Hodges, F. (2011). A dictionary of reading and related terms. Newark, NJ: International Reading Association.

John, T. (2015). Phonological wakefulness from research to practice. New York, NY: Guilford Press.

Kerr, N. (2009). The reading goal. Kennewick, WA: The New Foundation Press, Inc.

Killer, H. (2014). Towards a technology for assessing basic early literacy skills. School Psychology Review, 21 (6): 211-222.

Kothari, C.R. (2004). Research Methodology: Methods and Techniques, Second Revised Edition. New Delhi: New Age International Publishers.

Kumar, Y.S. (2006). Fundamental of Research Methodology and Statistics. New Delhi: New Age International (P) Ltd.

Luckner, J. (2013). Using the dynamic indicators of basic early literacy skills with students who are deaf or hard of hearing: Perspectives of a panel of experts. American Annals of the Deaf 158(1): 7-19.

Mani, S. (2008). Principles and practice of Education (2nded).Singapore: Longman.

Morrow, K. (2012). Lenses on reading: An introduction to theories and models. New York, NY: Guilford Press.

National Early Reading Literacy Panel (2008). Developing early literacy: Report of the National Early Panel. Washington, DC: National Institute for Literacy.

Nun, R. (2013). School reform from the inside out: Policy, practice, and performance. Cambridge, MA: Harvard University Press.

Paris, J. (2009). The Practices of English Language Teaching. 3rd ed. Harlow: Person Education Ltd.

Phillips, A. (2009). Teach English: A Training Course for teachers. Cambridge: CUP.

Sanders, Z. (2017). Cumulative and residual effects of teachers on future student academic achievement (Research Progress Report). Knoxville, TN: University of Tennessee Value-Added Research and Assessment Center.

Scott, D. 2008). Becoming a nation of readers: The report of the Commission on Reading. Champaign, III.: Center for the Study of Reading.

Shannon, M. (2010). The development of strategic readers. In R. Barr, M. I. Kamil, P. Rosenthal, \& P. D. Pearson (Eds.), Handbook of reading research (Vol. 4, pp. 507-591). New York: Longman.

Senior, A., (2005). Applying Educational Psychology in the Classroom. Longman Publishing Group, 4th Ed., London. 554P.

Tina, G. (2011). Ethiopia Early Grade Reading Assessment: Data Analysis Report: Language and Early Learning. Prepared by RTI for USAID.

Wake. P. (2013). Linking Reading Assessment to Instruction: An Application Work text for Elementary Classroom Teachers, Fourth Edition. USA: Lawrence Erlbaum Associates. Inc. 